\title{
Què està passant amb els isards?
}

Ignasi Marco i Santiago Lavín

Servei d'Ecopatologia de Fauna Salvatge, Dept. de Medicina i Cirurgia Animals, Facultat de Veterinària de la Universitat Autònoma de Barcelona

Des de fa alguns anys els isards del nostre país estan patint una greu epidèmia que ha reduït notablement la seva població. Què està passant?

\section{On podem veure isards? Com viuen?}

A Catalunya es troben isards en estat salvatge (fig. 1) en diverses zones del Pirineu i Pre-Pirineu. L'isard (Rupicapra pyrenaica) és un "mamífer artiodàctil remugant de la família dels bòvids, semblant a la cabra, amb banyes primes i corbades de la punta i pelatge fosc amb taques blanquinoses al cap, que habita les zones muntanyoses del sud d'Europa" (IEC, 2007).

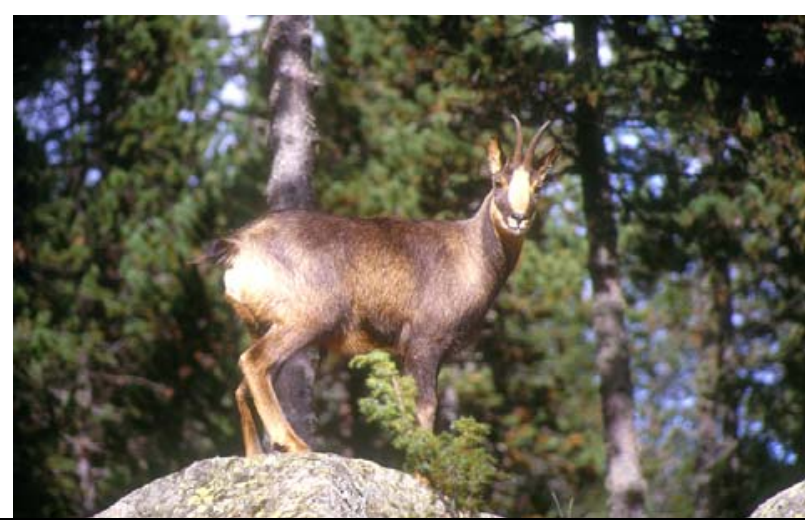

Figura 1. Un isard en el seu medi natural.

Els adults solen tenir una altura de llom d'uns 60 $\mathrm{cm}$ i pesar uns $30 \mathrm{~kg}$. A més del Pirineu també n'hi ha a la Serralada Cantàbrica i als Alps, entre altres llocs.

Després de la guerra del 36 la població d'isards a Catalunya estava sota mínims. Per a protegir-los, com a altres espècies cinegètiques, es començaren a crear, a partir de 1966, les reserves nacionals de caça. Actualment són les mostrades a la fig. 2. Al seu interior la cacera només s'autoritza amb determinades condicions.
De llavors ençà les poblacions d'isards en aquestes zones han anat augmentant, regulant-se mitjançant la cacera.

Cal dir que, sent herbívors com són, no perjudiquen els sembrats, inexistents en aquestes zones.

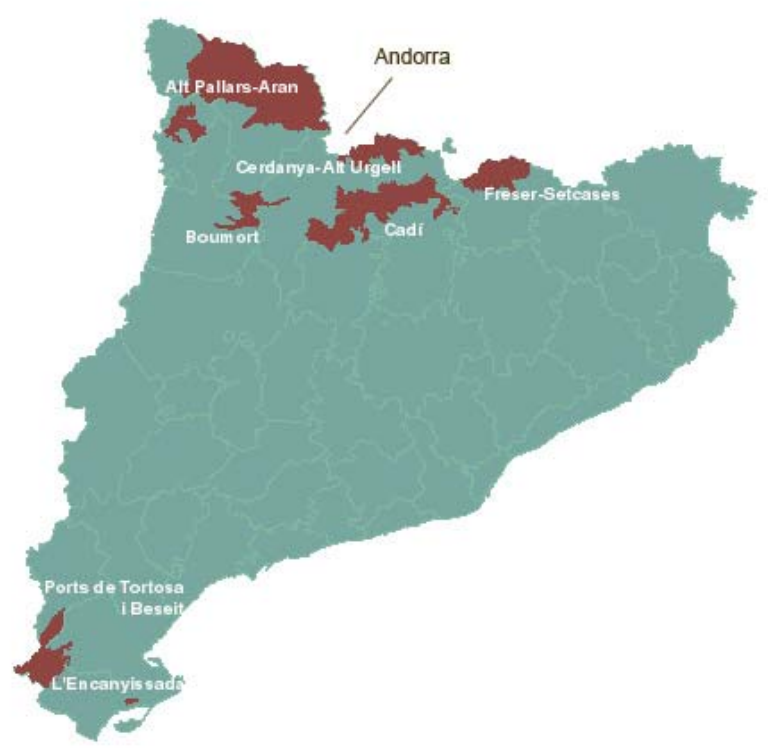

Figura 2. Reserves nacionals de caça, RNC. (Departament de Medi Ambient i Habitatge)

\section{Com comença la malaltia?}

El 2001 es detecta una mortaldat anormal d'isards a la part de la RNC de l'Alt Pallars-Aran propera a Andorra. Des de llavors, el Servei d'Ecopatologia de Fauna Salvatge de la Universitat Autònoma de Barcelona estudia el problema en el marc d'un conveni de col·laboració amb el Departament 
de Medi Ambient de la Generalitat per al seguiment de l'estat sanitari de les poblacions d'ungulats salvatges de Catalunya.

Els símptomes que presentaven els animals afectats no corresponien a cap malaltia coneguda en els isards. Tenien dificultats de moviment i debilitat. alguns havien canviat de comportament ja que no fugien de la presència humana, i fins i tot es deixaven capturar amb facilitat.

Vistos de prop presentaven desnutrició, paràsits abundants (paparres), debilitat del pèl, amb grans clapes on l'havia perdut (alopècia) (fig. 3) o que es desprenia amb facilitat, i zones de pigmentació cutània alterada (hiperpigmentació) (fig. 4).

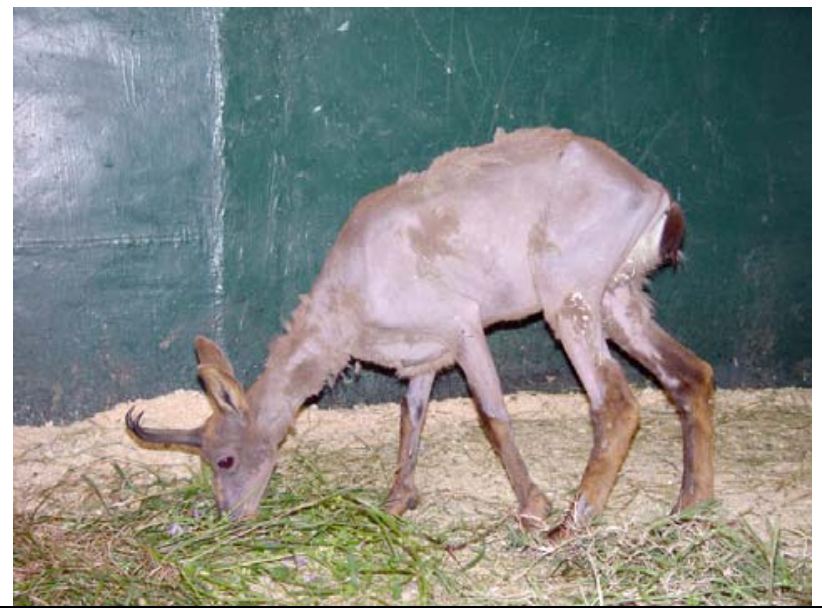

Figura 3. Un isard, capturat amb facilitat, mostrant una extensa alopècia.

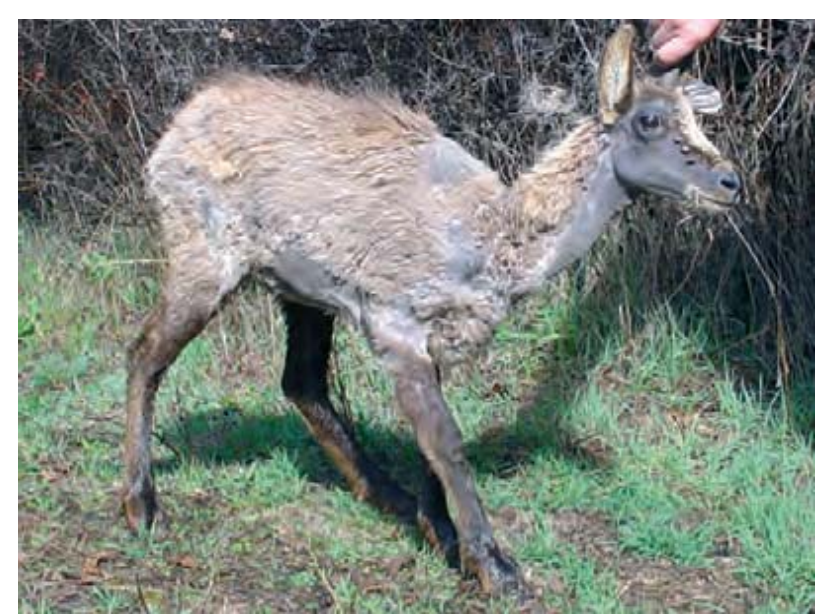

Figura 4. Isard capturat. Presenta aprimament, alopècia, paparres i hiperpigmentació cutània.

Ara sabem que la malaltia fa que els animals afectats es vagin aprimant, sofreixin una minva en les seves defenses que els fa més vulnerables a infeccions pulmonars, diarrees, etc. També els afecta el cervell.

\section{Quines dades tenim de l'epidèmia?}

Tractant-se d'una espècie salvatge que viu en un medi tan agrest és impossible saber el nombre exacte d'individus malalts o morts (fig. 5). L'única forma de tenir-ne una estimació és a partir de censos que es fan anualment a tot el Pirineu, sempre amb el mateix mètode.

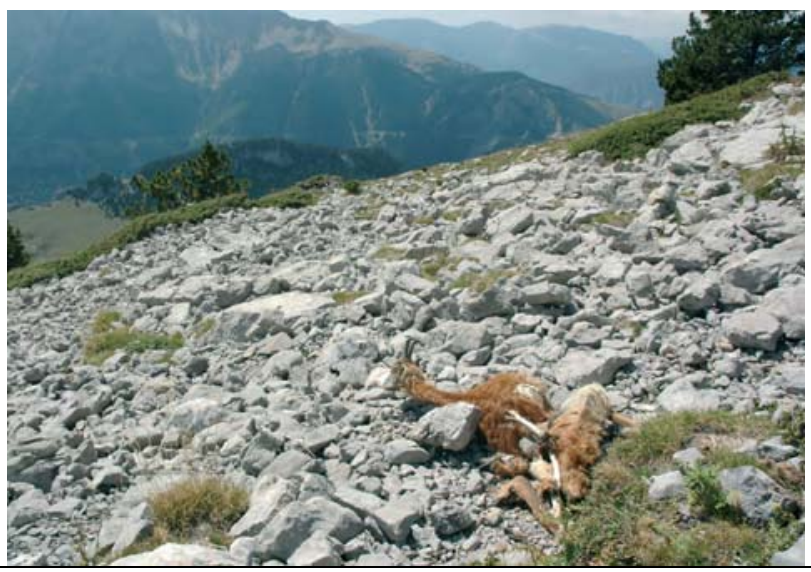

Figura 5. Restes d'un isard mort per la malaltia al Parc Natural del Cadí-Moixeró.

Algunes de les dades recollides en aquests censos han mostrat percentatges de mortalitat força elevats en alguns moments, així com moments de remissió (taula 1).

\begin{tabular}{|l|l|l|}
\hline Període & Zona & Mortalitat (\%) \\
\hline 2001-2002 & Pallars Sobirà & $40-45$ \\
\hline $2000-2002$ & Vall Ferrera & 40 \\
\hline $2000-2002$ & Cardós & 45 \\
\hline $2003-2004$ & Pirineu i Pre-Pirineu & 0 \\
\hline 2005 & Cerdanya & 80 \\
\hline $2005-2006$ & Cadí & 70 \\
\hline
\end{tabular}

Taula 1. Mortalitat d'isards en algunes temporades i zones.

La malaltia sembla haver-se desplaçat cap a l'est pel vessant nord del Pirineu, ja que al vessant sud no n'hi ha hagut casos durant el 2003 i 2004 però sí a les zones franceses.

\section{Quina és la causa de la malaltia?}

S'han realitzat analítiques molt àmplies dels animals malalts o morts, així com dels que han estat caçats. S'ha trobat que la causa de la malaltia és un virus del gènere Pestivirus que ja s'ha pogut 
aïllar i estudiar. No es tracta de cap soca prèviament descrita, però té semblances amb Pestivirus de tipus oví. La pesta porcina clàssica és causada també per un Pestivirus i és molt mortal i contagiosa.

Cada brot ha estat diferent. Tot i que els virus han estat els mateixos, les malalties secundàries han estat diferents. També ha variat la immunitat de la població: en poblacions amb defenses no ha aparegut, com a Freser-Setcases, però s'ha acarnissat en les que les tenien debilitades, com al Cadí. Pot ser que els isards hagin tingut contacte amb els Pestivirus de les ovelles: encara que no són iguals, potser els hagi protegit fent-los desenvolupar anticossos.

Estudiant mostres antigues, s'ha pogut demostrar que el Pestivirus ja apareixia en mostres del 1996. Una mutació el pot haver tornat molt més patogen.

Cal dir que aquests virus no afecten les persones.

\section{Quines mesures es poden prendre?}

Les mesures més elementals són intentar retirar el animals malalts per disminuir el risc de contagi, i suspendre la cacera d'una població que va a la baixa. Es continua fent un cens anual i un seguiment més proper de la població.

Per altra banda s'avança en l'estudi de la malaltia. No es busca una vacuna, doncs és impossible vacunar animals en estat salvatge. El que es farà és intentar reproduir experimentalment la malaltia a partir del virus per conèixer millor el seu funcionament. Ara es disposa dels recursos econòmics per poder fer-ho i pot aportar el coneixement necessari per ajudar a controlar la malaltia.

\section{Bibliografia}

IEC (2007). Diccionari de la Llengua Catalana, segona edició. http://dlc.iec.cat/

MARCO, I. i LAVIN, S. (2007). El pestivirus del rebeco del Pirineo. Pequeños rumiantes 8 , número 1: 28-31. 